\title{
Novel dipeptidyl peptidase IV resistant analogues of glucagon-like peptide-1(7-36)amide have preserved biological activities in vitro conferring improved glucose-lowering action in vivo
}

\section{B D Green, V A Gault, M H Mooney, N Irwin, C J Bailey ${ }^{1}$, P Harriott ${ }^{2}$, B Greer ${ }^{2}$, P R Flatt and F P M O'Harte}

School of Biomedical Sciences, University of Ulster, Coleraine BT52 1SA, Northern Ireland, UK

${ }^{1}$ Department of Pharmaceutical and Biological Sciences, Aston University, Birmingham, UK

${ }^{2}$ Centre for Peptide and Protein Engineering, School of Biology and Biochemistry, The Queen's University of Belfast, Belfast BT9 7BL, Northern Ireland, UK

(Requests for offprints should be addressed to B D Green; Email: b.green@ulster.ac.uk)

\begin{abstract}
Although the incretin hormone glucagon-like peptide-1 (GLP-1) is a potent stimulator of insulin release, its rapid degradation in vivo by the enzyme dipeptidyl peptidase IV (DPP IV) greatly limits its potential for treatment of type 2 diabetes. Here, we report two novel Ala ${ }^{8}$-substituted analogues of GLP-1, $\left(\mathrm{Abu}^{8}\right) \mathrm{GLP}-1$ and $\left(\mathrm{Val}^{8}\right) \mathrm{GLP}-1$ which were completely resistant to inactivation by DPP IV or human plasma. $\left(\mathrm{Abu}^{8}\right) \mathrm{GLP}-1$ and $\left.(\mathrm{Val})^{8}\right) \mathrm{GLP}-1$ exhibited moderate affinities $\left(\mathrm{IC}_{50}: 4.76\right.$ and $81.1 \mathrm{nM}$, respectively) for the human GLP-1 receptor compared with native GLP-1 (IC $\left.{ }_{50}: 0.37 \mathrm{nM}\right)$. (Abu $)^{8} \mathrm{GLP}-1$ and $\left(\mathrm{Val}^{8}\right)$ GLP-1 dose-dependently stimulated CAMP in insulin-secreting BRIN BD11 cells with reduced potency compared with native GLP-1 (1.5- and 3.5-fold, respectively). Consistent with other mechanisms of action, the analogues showed similar, or in the case of $\left(\left.\mathrm{Val}\right|^{8}\right) \mathrm{GLP}-1$ slightly impaired insulin releasing activity in BRIN BD11 cells. Using adult obese $(o b / o b)$ mice, $\left(\mathrm{Abu}^{8}\right) \mathrm{GLP}-1$ had similar glucose-lowering potency to native GLP-1 whereas the action of $\left(\mathrm{Val}^{8}\right) \mathrm{GLP}-1$ was enhanced by $37 \%$. The in vivo insulin-releasing activities were similar. These data indicate that substitution of $\mathrm{Ala}^{8}$ in GLP-1 with Abu or Val confers resistance to DPP IV inactivation and that $\left(\mathrm{Val}^{8}\right) \mathrm{GLP}-1$ is a particularly potent $\mathrm{N}$-terminally modified GLP-1 analogue of possible use in type 2 diabetes.
\end{abstract}

Journal of Molecular Endocrinology (2003) 31, 529-540

\section{Introduction}

Glucagon-like peptide-1(7-36)amide (GLP-1) is produced in the L cells of the small intestine by the tissue-specific post-translational processing of the product of the proglucagon gene (Bell et al. 1983). Upon ingestion of a meal, GLP-1 is released into the circulation (Fehmann et al. 1995) where it acts to stimulate insulin release from pancreatic $\beta$ cells through interaction with specific receptors that are coupled to the stimulatory $\mathrm{G}$ protein (Thorens et al. 1993). Apart from its direct effect on insulin secretion, GLP-1 has been shown to increase the rate of insulin biosynthesis (Fehmann \& Habener 1992) and to restore the ability of the $\beta$ cell to respond to glucose (Wang et al. 1997). Recent studies have highlighted mitogenic effects of GLP-1 on the pancreas and this has been associated with an ability to direct cell differentiation (Abraham et al. 2002) and increase $\beta$-cell mass (Tourrel et al. 2002). In addition to possessing potent insulinotrophic activity, GLP-1 also inhibits the release of glucagon (Ritzel et al. 1995) and both of these actions are glucose-dependent (Kreymann et al. 
1987). Further metabolic properties of GLP-1 include peripheral effects such as inhibition of feeding (Turton et al. 1996) and reduction of gastrointestinal motility and secretion (Wettergren et al. 1993). Glycogenic effects of GLP-1 in liver, skeletal muscle and abdominal muscle (Valverde et al. 1994, Villanueva-Peñacarrillo et al. 1994, O'Harte et al. 1997) and lipogenic effects in adipose tissue (Oben et al. 1991, Perea et al. 1997) have also been reported, although there is no reproducible evidence that a GLP-1 receptor exists in these tissues (Bullock et al. 1996).

As most of the described properties of GLP-1 appear to be directly involved in lowering blood glucose, attention has focused on using GLP-1 as a therapeutic agent in the treatment of type 2 diabetes in man (Gutniak et al. 1992, Nathan et al. 1992, Nauck et al. 1996, Rachman 1996, Zander et al. 2002). However, a major limiting factor in such a use for GLP-1 is its susceptibility to degradation and inactivation in vivo by dipeptidyl peptidase IV (DPP IV; EC.3·4·14·5) - a member of the prolyl oligopeptidase family of serine proteases (Barrett \& Rawlings 1992). DPP IV is ubiquitously found in mammalian organs and tissues including serum (Iwaki-Egawa et al. 1998) and cleaves peptides that contain penultimate proline, alanine or hydroxyproline residues (Mentlein 1999). In the case of GLP-1, DPP IV rapidly $\left(t_{1 / 2} 2-3 \mathrm{~min}\right)$ cleaves the $\mathrm{His}^{7}-\mathrm{Ala}^{8}$ dipeptide from the N-terminus generating GLP-1(9-36)amide (Mentlein et al. 1993). This truncated form of GLP-1 is inactive and may even behave as a receptor antagonist (Knudsen \& Pridal 1996, Wettergren et al. 1998).

Various attempts have been made to prevent the degradation of GLP-1 by DPP IV through modification at the N-terminus (Deacon et al. 1998, Burcelin et al. 1999, O'Harte et al. 2001). In this study, the stability and activity of $\left(\mathrm{Abu}^{8}\right) \mathrm{GLP}-1$ and $\left(\mathrm{Val}^{8}\right)_{\text {GLP-1 }}$ were examined. These novel GLP-1 analogues were prepared through substitution of the alanine at position 8 of GLP-1 with residues possessing a marginally larger side-chain. The in vitro stability, receptor binding affinity, cAMP production and insulinotropic activity of these analogues were investigated. In addition, we evaluated the effectiveness of these modified forms of GLP-1 following administration in obese diabetic $(o b / o b)$ mice - a commonly used animal model of type 2 diabetes mellitus.

\section{Materials and methods}

\section{Reagents}

High performance liquid chromatography HPLC grade acetonitrile was obtained from Rathburn (Walkersburn, Scotland). Sequencing grade trifluoroacetic acid (TFA), dipeptidyl peptidase IV (DPP IV), forskolin (FSK), isobutylmethylxanthine (IBMX), adenosine $3^{\prime}, 5^{\prime}$-cyclic monophosphate (cAMP) and adenosine $5^{\prime}$-triphosphate (ATP) were all purchased from Sigma (Poole, Dorset, UK). Fmoc-protected amino acids were obtained from Calbiochem Novabiochem (Beeston, Nottingham, UK). RPMI-1640 and DMEM tissue culture medium, fetal bovine serum (FBS), penicillin and streptomycin were all purchased from Gibco (Paisley, Strathclyde, Scotland). The chromatography columns used for cAMP assay, Dowex AG50 WX and neutral alumina AG7, were obtained from Bio-Rad (Life Science Research, Alpha Analytical, Larne, N. Ireland). Tritiated adenine (TRK311) was obtained from Amersham Pharmacia Biotech, Bucks, UK. All water used in these experiments was purified using a Milli-Q Water Purification System (Millipore, Milford, MA, USA). All other chemicals used were of the highest available purity.

\section{Synthesis and purification of GLP-1, $\left(A b u^{8}\right) G L P-1$ and $\left(\mathrm{Val}^{8}\right) \mathrm{GLP}-1$}

Peptide synthesis was carried out on an Applied Biosystems automated peptide synthesiser (model 432A) using standard solid-phase Fmoc (N-(9fluorenyl)methoxycarbonyl) protocols (Fields \& Noble 1990), starting with a rink amide MBHA resin. Synthetic peptides were cleaved from the resin and purified by reversed-phase HPLC on a Waters Millenium 2010 chromatography system (software version $2 \cdot 1 \cdot 5$ ).

\section{Electrospray ionisation-mass spectrometry (ESI-MS)}

Intact and degradation fragments of GLP-1, $\left(\mathrm{Abu}^{8}\right)$ GLP-1 and $\left(\mathrm{Val}^{8}\right)$ GLP-1 were dissolved in water and eluted under isocratic conditions using an ion trap LCQ benchtop LC mass spectrometer (LC/MS; Finnigan MAT, Hemel Hempstead, UK). Mass spectra were collected using full ion scan mode over the mass-to-charge $(\mathrm{m} / \mathrm{z})$ range 150-2000. The molecular masses of each fragment 
were determined using prominent multiple-charged ions and the following equation applied: $\mathrm{M}_{\mathrm{r}}=\mathrm{iM}_{\mathrm{i}}-\mathrm{iM}_{\mathrm{h}}$, where $\mathrm{M}_{\mathrm{r}}$ is molecular mass, $\mathrm{M}_{\mathrm{i}}$ is $m / z$ ratio, $i$ is the number of charges, and $\mathbf{M}_{h}$ is the mass of a proton.

\section{Degradation of GLP-1, $\left(A b u^{8}\right) G L P-1$ and $\left(\mathrm{Val}^{8}\right) G L P-1$ by DPP IV and human plasma}

HPLC-purified peptides were incubated in vitro at $37^{\circ} \mathrm{C}$ in $50 \mathrm{mM}$ triethanolamine-HCl $(\mathrm{pH} 7 \cdot 8$, final peptide concentration $2 \mathrm{mM}$ ) with either DPP IV $(1 \cdot 25 \mathrm{mU})$ or pooled human plasma $(7 \cdot 5 \mu \mathrm{l})$ for 0,6 and $12 \mathrm{~h}$. The enzymatic reactions were terminated by the addition of $15 \mu \mathrm{l} 10 \% \quad(\mathrm{v} / \mathrm{v})$ TFA/water. The reaction products were then applied to a Vydac C-18 column $(4 \cdot 6 \times 250 \mathrm{~mm})$ and the major degradation fragment GLP-1(936)amide was separated from intact GLP-1, $\left(\mathrm{Abu}^{8}\right) \mathrm{GLP}-1$ and $\left(\mathrm{Val}^{8}\right)$ GLP-1. The column was equilibrated with $0 \cdot 12 \%(\mathrm{v} / \mathrm{v}) \mathrm{TFA} /$ water at a flow rate of $1.0 \mathrm{ml} / \mathrm{min}$. Using $0 \cdot 1 \%(\mathrm{v} / \mathrm{v})$ TFA in $70 \%$ acetonitrile/water, the concentration of acetonitrile in the eluting solvent was raised from $0 \%$ to $28 \%$ over $10 \mathrm{~min}$, and from $28 \%$ to $42 \%$ over $30 \mathrm{~min}$. The absorbance was monitored at 206 nm using a SpectraSystem UV 2000 detector (Thermoquest Limited, Manchester, UK) and peaks were collected manually prior to ESI-MS analysis.

\section{Cells and cell culture}

Chinese hamster lung (CHL) fibroblasts stably transfected with the human GLP-1 receptor (Thorens et al. 1993) were cultured using DMEM tissue culture medium containing 10\% (v/v) FBS, and $1 \%(\mathrm{v} / \mathrm{v})$ antibiotics $(100 \mathrm{U} / \mathrm{ml}$ penicillin, $0.1 \mathrm{mg} / \mathrm{ml}$ streptomycin and $0.2 \mathrm{mg} / \mathrm{ml}$ gentimycin). BRIN-BD11 cells were cultured using RPMI-1640 tissue culture medium containing 10\% $(\mathrm{v} / \mathrm{v})$ FBS, $1 \%$ (v/v) antibiotics $(100 \mathrm{U} / \mathrm{ml}$ penicillin, $0.1 \mathrm{mg} / \mathrm{ml}$ streptomycin) and $11 \cdot 1 \mathrm{mM}$ glucose. The origin and insulin secretory characteristics of these cells have been described previously (McClenaghan et al. 1996). All cells were maintained in sterile tissue culture flasks (Corning, Glass Works, Sunderland, UK) at $37{ }^{\circ} \mathrm{C}$ in an atmosphere of $5 \% \mathrm{CO}_{2}$ and $95 \%$ air using a LEEC incubator (Laboratory Technical Engineering, Nottingham, UK).

\section{Receptor binding studies}

CHL fibroblasts stably transfected with the human GLP-1 receptor were seeded at a density of $1 \times 10^{5}$ cells per well into 24-multiwell plates (Nunc, Roskilde, Denmark). Following overnight culture at $37^{\circ} \mathrm{C}$, cells were washed twice with cold HBS buffer $(130 \mathrm{mM} \mathrm{NaCl}, 20 \mathrm{mM}$ HEPES, $0.9 \mathrm{mM}$

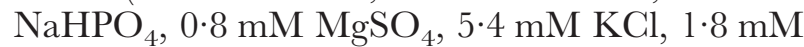
$\mathrm{CaCl}_{2}, 25 \mathrm{mM}$ glucose, $25 \mu \mathrm{M}$ phenol red, $\mathrm{pH} 7 \cdot 4$ ). Test incubations were performed in HBS buffer $(400 \mu \mathrm{l})$ with a range of concentrations $\left(10^{-12}\right.$ to $\left.10^{-6} \mathrm{M}\right)$ of GLP-1, $\left(\mathrm{Abu}^{8}\right) \mathrm{GLP}-1$ or $\left(\mathrm{Val}^{8}\right) \mathrm{GLP}-1$ plus ${ }^{125}$ I-GLP-1 label (50 000 c.p.m./ml) and phenylmethylsuphonylfluoride $(1 \mathrm{mM}) .{ }^{125} \mathrm{I}-\mathrm{GLP}-1$ was prepared by the iodogen method (Salacinski et al. 1981). Following incubation for $24 \mathrm{~h}$ at $4{ }^{\circ} \mathrm{C}$, cells were washed four times with cold saline solution $(0 \cdot 85 \% \mathrm{NaCl})$ and $500 \mu \mathrm{l}$ lysis solution $(5 \%$ trichloroacetic acid; 3\% sodium dodecyl sulphate) were added. Plates were shaken for $10 \mathrm{~min}, 1 \mathrm{ml}$ millipore water was added, the content of the wells was removed and radioactivity was measured on a $\gamma$-counter (1261 Multigamma counter, LKB Wallac, Turku, Finland). Curves were analysed by non-linear regression using the sigmoidal dose-response equation to calculate $\mathrm{IC}_{50}$ values.

\section{Effects of GLP-1, $\left(A b u^{8}\right) G L P-1$ and $\left(V a l^{8}\right) G L P-1$ on cyclic AMP production}

BRIN-BD11 cells were seeded into 24-multiwell plates at a density of $3 \cdot 0 \times 10^{5}$ cells per well. The cells were then allowed to grow in culture for $48 \mathrm{~h}$ before being pre-incubated $\left(16 \mathrm{~h}\right.$ at $\left.37^{\circ} \mathrm{C}\right)$ in media supplemented with tritiated adenine $(2 \mu \mathrm{Ci})$. The cells were then washed twice with cold HBS buffer. The cells were then exposed for $20 \mathrm{~min}$ at $37^{\circ} \mathrm{C}$ to varying concentrations $\left(10^{-12}\right.$ to $\left.10^{-6} \mathrm{M}\right)$ of GLP-1, $\left(\mathrm{Abu}^{8}\right)$ GLP-1, $\left(\mathrm{Val}^{8}\right) \mathrm{GLP}-1$ or forskolin $(10 \mu \mathrm{M})$ in HBS buffer, in the presence of $1 \mathrm{mM}$ IBMX. The medium was subsequently removed and $1 \mathrm{ml}$ lysis solution added containing $0.3 \mathrm{mM}$ unlabelled cAMP and $5 \mathrm{mM}$ unlabelled ATP. The intracellular tritiated cAMP was then separated on Dowex and alumina exchange resins as previously described (Miguel et al. 2003).

\section{In vitro insulin secretion}

BRIN-BD11 cells were seeded into 24-multiwell plates at a density of $1 \cdot 0 \times 10^{5}$ cells per well, and 
allowed to attach overnight at $37^{\circ} \mathrm{C}$. Acute tests for insulin release were preceded by $40 \mathrm{~min}$ preincubation at $37^{\circ} \mathrm{C}$ in $1.0 \mathrm{ml}$ Krebs Ringer bicarbonate buffer $(115 \mathrm{mM} \mathrm{NaCl}, 4.7 \mathrm{mM} \mathrm{KCl}$, $1.28 \mathrm{mM} \quad \mathrm{CaCl}_{2}, \quad 1.2 \mathrm{mM} \quad \mathrm{KH}_{2} \mathrm{PO}_{4}, \quad 1.2 \mathrm{mM}$ $\mathrm{MgSO}_{4}, 10 \mathrm{mM} \mathrm{NaHCO}, 0.5 \%$ (w/v) BSA, pH $7 \cdot 4)$ supplemented with $1.1 \mathrm{mM}$ glucose. Test incubations were performed in the presence of $5.6 \mathrm{mM}$ glucose with a range of concentrations $\left(10^{-12}\right.$ to $\left.10^{-6} \mathrm{M}\right)$ of GLP-1, $\left(\mathrm{Abu}^{8}\right) \mathrm{GLP}-1$ or $\left(\mathrm{Val}^{8}\right)$ GLP-1. After $20 \mathrm{~min}$ incubation, the buffer was removed from each well and aliquots $(200 \mu \mathrm{l})$ were used in insulin RIA.

\section{Effects of GLP-1, $\left(A b u^{8}\right) G L P-1$ and $\left(V a l^{8}\right) G L P-1$ in (ob/ob) mice}

Evaluation of the effects of GLP-1, $\left(\mathrm{Abu}^{8}\right) \mathrm{GLP}-1$ or $\left(\mathrm{Val}^{8}\right)$ GLP-1 on plasma glucose and insulin concentrations were examined using 12- to 16 -week-old obese diabetic $(o b / o b)$ mice. The genetic background and characteristics of the colony used have been outlined elsewhere (Bailey et al. 1982). The animals were housed individually in an air-conditioned room at $22 \pm 2{ }^{\circ} \mathrm{C}$ with a $12 \mathrm{~h}$ light:12 h darkness cycle. Drinking water and a standard rodent maintenance diet (Trouw Nutrition Ltd, Cheshire, UK) were freely available. Food was withdrawn for an 18 -h period prior to i.p. injection of saline $(0.9 \%(\mathrm{w} / \mathrm{v}) \quad \mathrm{NaCl})$ as control, glucose alone $(18 \mathrm{mmol} / \mathrm{kg}$ body weight) or in combination with GLP-1, $\left(\mathrm{Abu}^{8}\right)$ GLP-1 or $\left(\mathrm{Val}^{8}\right)$ GLP-1 (each at $25 \mathrm{nmol} / \mathrm{kg}$ ). All test solutions were administered in a final volume of $8 \mathrm{ml} / \mathrm{kg}$ body weight. Blood samples were collected from the cut tip of the tail vein of conscious mice into chilled fluoride/heparin microcentrifuge tubes (Sarstedt, Nümbrecht, Germany) immediately prior to injection and at 15, 30 and $60 \mathrm{~min}$ post injection. Plasma was aliquoted and stored at $-20{ }^{\circ} \mathrm{C}$ for subsequent glucose and insulin determinations. All animal studies were carried out in accordance with the UK Animals (Scientific Procedures) Act 1986.

\section{Analyses}

Plasma glucose was assayed by an automated glucose oxidase procedure using a Beckman Glucose Analyser II (Stevens 1971). Plasma insulin was determined by dextran-charcoal RIA as described previously (Flatt \& Bailey 1981). Incremental areas under the plasma glucose and insulin curves (AUC) were calculated using Graphpad PRISM version 3.0 (GraphPad Software, San Diego, CA, USA) which employs the trapezoidal rule (Burington 1973). Results are expressed as means \pm S.E.M. and data were compared, as appropriate, using the Student's $t$-test, repeated measures ANOVA or one-way ANOVA, followed by the Student-Newman-Keuls post hoc test. Groups of data were considered to be significantly different if $P<0 \cdot 05$.

\section{Results}

\section{Synthesis and purification of peptides}

Table 1 shows the monoisotopic masses obtained using ESI-MS for synthesised and purified GLP-1, $\left(\mathrm{Val}^{8}\right)_{\text {GLP-1 }}$ and $\left(\mathrm{Abu}^{8}\right)$ GLP-1. Following spectral averaging, prominent multiple-charged species $(\mathrm{M}+2 \mathrm{H})^{2+}$ and $(\mathrm{M}+3 \mathrm{H})^{3+}$ were obtained for GLP-1, corresponding to an intact $\mathrm{M}_{\mathrm{r}}$ of 3297.3 Da (theoretical mass 3297.5 Da); similarly, for $\left(\mathrm{Abu}^{8}\right)$ GLP-1 corresponding to intact $\mathrm{M}_{\mathrm{r}}$ of $3310 \cdot 6 \mathrm{Da}$ (theoretical mass $3311 \cdot 7 \mathrm{Da}$ ), and finally for $\left(\mathrm{Val}^{8}\right)$ GLP-1, corresponding to an $\mathrm{M}_{\mathrm{r}}$ of $3324 \cdot 4 \mathrm{Da}$ (theoretical mass $3325 \cdot 7 \mathrm{Da}$ ).

\section{Degradation of GLP-1, $\left(A b u^{8}\right) G L P-1$ and $\left(\mathrm{Val}^{8}\right) \mathrm{GLP}-1$ by DPP IV and human plasma}

GLP-1 was progressively metabolised by DPP IV over the 12-h period (47-82\% degraded) giving rise to the appearance of a second peak corresponding to the degradation fragment GLP-1(9-36)amide. As shown in Table 1, similar incubation of GLP-1 with human plasma resulted in progressive metabolism with $78 \%$ degraded by $12 \mathrm{~h}$. In contrast, when $\left(\mathrm{Abu}^{8}\right)$ GLP-1 and $\left(\mathrm{Val}^{8}\right) \mathrm{GLP}-1$ were incubated under similar conditions with DPP IV or human plasma, no formation of GLP-1(9-36)amide could be detected (Table 1).

\section{Determination of GLP-1 receptor binding in $\mathrm{CHL}$ fibroblasts}

The ability of GLP-1, $\left(\mathrm{Abu}^{8}\right) \mathrm{GLP}-1$ or $\left(\mathrm{Val}^{8}\right) \mathrm{GLP}-1$ to inhibit the binding of ${ }^{125}$ I-GLP-1 to $\mathrm{CHL}$ 
Table 1 Molecular characterisation and susceptibility of GLP-1 peptides to degradation by DPP IV and human plasma

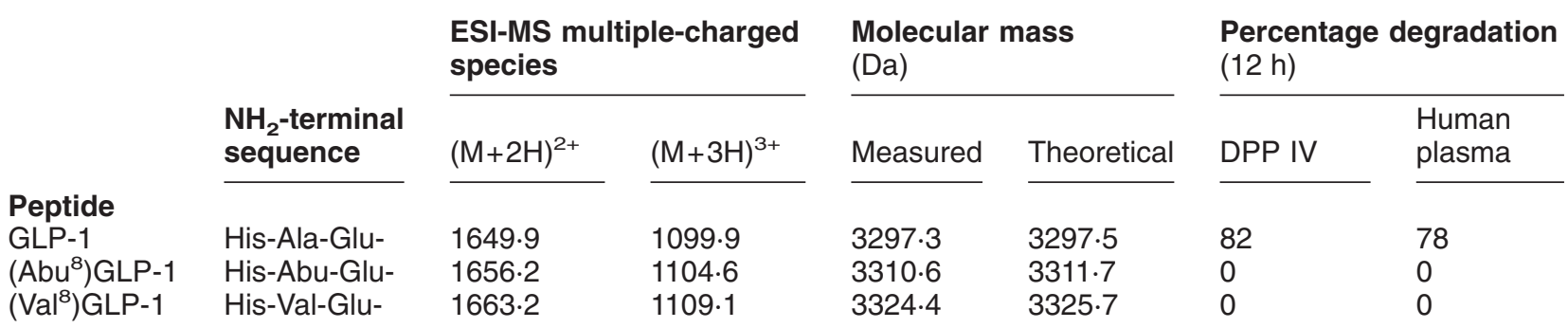

The peptides were applied to LC/MS equipped with a microbore C-18 HPLC column (150 mm×2.0 mm) at a flow rate of $0.2 \mathrm{ml} / \mathrm{min}$, under isocratic conditions in $35 \%(\mathrm{v} / \mathrm{v})$ acetonitrile/water. Spectra were recorded using a quadripole ion trap mass analyser and collected using full ion scan mode over the $\mathrm{m} / \mathrm{z}$ range 150-2000. Data represent the percentage of major degradation fragment, GLP-1(9-36)amide (following HPLC separation), relative to the intact peptide following incubation with purified DPP IV or human plasma.

fibroblast cells transfected with the human GLP-1 receptor is shown in Fig. 1. GLP-1 and GLP-1 analogues were all found to dose-dependently displace the radiolabelled tracer. Displacement by GLP-1 was complete at $10 \mathrm{nM}$ and half-maximal inhibition of ${ }^{125} \mathrm{I}-\mathrm{GLP}-1$ binding $\left(\mathrm{IC}_{50}\right)$ was observed at a GLP-1 concentration of $0 \cdot 37 \mathrm{nM} .\left(\mathrm{Abu}^{8}\right) \mathrm{GLP}-1$ and $\left(\mathrm{Val}^{8}\right) \mathrm{GLP}-1$ were found to have slightly lower binding affinities

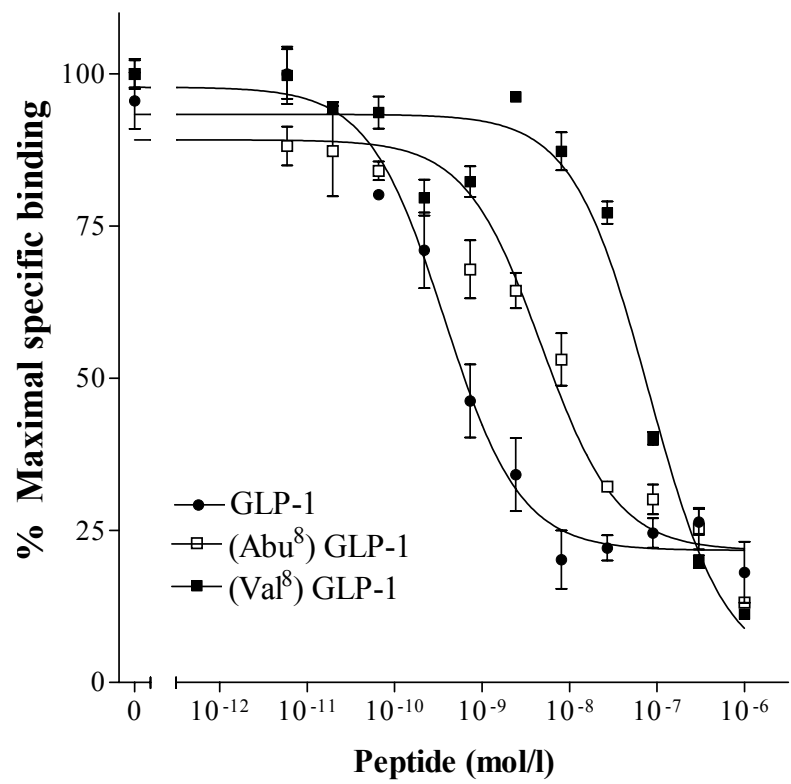

Figure 1 Displacement of ${ }^{125} \mathrm{I}-\mathrm{GLP}-1$ by unlabelled GLP-1, $\left(\mathrm{Abu}^{8}\right) \mathrm{GLP}-1$ and $\left(\mathrm{Val}^{8}\right)^{8} \mathrm{GLP}-1$ in $\mathrm{CHL}$ fibroblasts stably transfected with the human GLP-1 receptor. Values represent means \pm S.E.M. for three different experiments. as defined by their ability to inhibit tracer binding with $\mathrm{IC}_{50}$ values of $4.76 \mathrm{nM}$ and $81 \cdot 1 \mathrm{nM}$, respectively.

Stimulation of adenylate cyclase by GLP-1, $\left(A b u^{8}\right) G L P-1$ and $\left(V a l^{8}\right) G L P-1$

The dose-dependent stimulatory effects of GLP-1, $\left(\mathrm{Abu}^{8}\right) \mathrm{GLP}-1$ or $\left(\mathrm{Val}^{8}\right) \mathrm{GLP}-1$ on intracellular cAMP production following incubation with BRIN-BD11 cells are shown in Fig. 2. At the highest concentrations, $10^{-6}$ and $10^{-5} \mathrm{M}$, both GLP-1 and its analogues induced the same maximal rise in cAMP levels. The concentrations of GLP-1, $\left(\mathrm{Abu}^{8}\right) \mathrm{GLP}-1$ or $\left(\mathrm{Val}^{8}\right) \mathrm{GLP}-1$ that produced $50 \%$ maximal formation of $\mathrm{cAMP}\left(\mathrm{EC}_{50}\right)$ were approximately $4 \cdot 7,7 \cdot 2$ and $16 \cdot 4 \mathrm{nM}$ respectively. These values show good correlation with the relative affinity of GLP-1, $\left(\mathrm{Abu}^{8}\right) \mathrm{GLP}-1$ and $\left(\mathrm{Val}^{8}{ }^{\mathrm{S}}\right.$ GLP-1 for the GLP-1 receptor (Fig. 1).

\section{Insulinotropic action of $G L P-1,\left(A b u^{8}\right) G L P-1$ and $\left.(\mathrm{Val})^{8}\right) G L P-1$}

Figure 3 shows the effect of increasing concentrations of GLP-1, $\left(\mathrm{Abu}^{8}\right) \mathrm{GLP}-1$ and $\left(\mathrm{Val}^{8}\right) \mathrm{GLP}-1$ on insulin secretion from the glucose-responsive clonal pancreatic $\beta$-cell line, BRIN-BD11, in the presence of (A) $5.6 \mathrm{mM}$ glucose or (B) a supraphysiological $16.7 \mathrm{mM}$ glucose concentration. Figure $3 \mathrm{~A}$ shows that all peptides stimulated insulin release $(1 \cdot 4$ - to $5 \cdot 4$-fold; $P<0 \cdot 05$ to $P<0 \cdot 001)$ in a dose-dependent manner between $10^{-12}$ and 


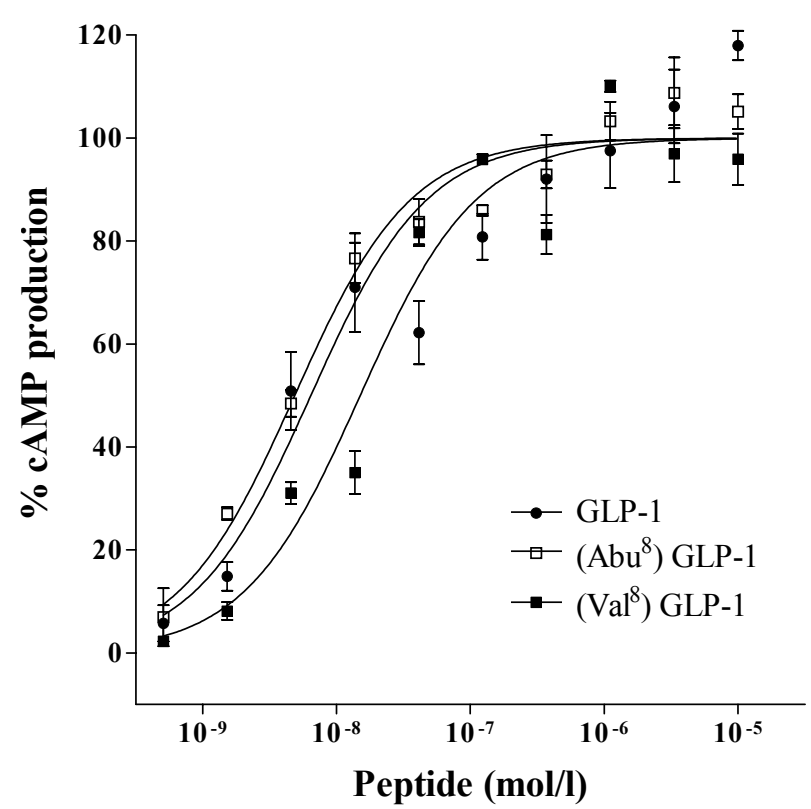

Figure 2 Intracellular cAMP production in BRIN-BD11 cells exposed for $20 \mathrm{~min}$ to various concentrations of GLP-1, $\left(\mathrm{Abu}^{8}\right)$ GLP-1 and $\left.(\mathrm{Val})^{8}\right) \mathrm{GLP}-1$. Each experiment was performed in triplicate $(n=3)$ and the data expressed (means \pm S.E.M.) as a percentage of the forskolin $(10 \mu \mathrm{M})$ response.

$10^{-6} \mathrm{M}$ compared with control $(5 \cdot 6 \mathrm{mM}$ glucose). Compared with native GLP-1, $\left(\mathrm{Abu}^{8}\right) \mathrm{GLP}-1$ was equipotent at stimulating insulin release over the entire concentration range. In contrast, $\left(\mathrm{Val}^{8}\right)$ GLP-1 exhibited significantly reduced effects on insulin secretion at $10^{-8}$ and $10^{-7} \mathrm{M}$ compared with GLP-1 but was equipotent at all other concentrations. At $16.7 \mathrm{mM}$ glucose (Fig. 3B), the peptides similarly stimulated insulin secretion but the overall responses were increased, demonstrating the glucose-dependent nature of GLP-1 peptides. GLP-1, $\left(\mathrm{Abu}^{8}\right) \mathrm{GLP}-1$ and $\left(\mathrm{Val}^{8}\right)$ GLP-1 enhanced glucose-induced insulin secretion by $1 \cdot 2$ - to $5 \cdot 6$-fold $(P<0 \cdot 05$ to $P<0 \cdot 001)$ when compared with control. $\left(\mathrm{Abu}^{8}\right) \mathrm{GLP}-1$ was again found to be equipotent to GLP-1 over the entire concentration range whilst $\left(\mathrm{Val}^{8}\right)$ GLP-lexhibited significantly reduced potency from $10^{-9}$ to $10^{-7} \mathrm{M}$. Interestingly, $\left(\mathrm{Val}^{8}\right) \mathrm{GLP}-1$ and $\left(\mathrm{Abu}^{8}\right) \mathrm{GLP}-1$ were found to have significantly enhanced potency at the lowest peptide concentrations $\left(10^{-12}\right.$ to $\left.10^{-11} \mathrm{M}\right)$ when compared with native GLP-1.
Effects of GLP-1, $\left(A b u^{8}\right) G L P-1$ and $\left(V_{a l}{ }^{8}\right) G L P-1$ on glucose lowering and insulin secretion in obese diabetic (ob/ob) mice

Figures 4 and 5 show the plasma glucose and insulin responses to i.p. administration of saline control, glucose alone or in combination with GLP-1, $\left(\mathrm{Abu}^{8}\right)$ GLP-1 or $\left(\mathrm{Val}^{8}\right)$ GLP-1 in obese diabetic $(o b / o b)$ mice. Saline had no effect on plasma glucose concentration (Fig. 4A). After injection of glucose alone, plasma glucose rose significantly at $15 \mathrm{~min}(P<0.001)$ and remained at elevated levels even after $60 \mathrm{~min}$. Plasma glucose levels $15 \mathrm{~min}$ after native GLP-1 administration $(28 \cdot 2 \pm 3 \cdot 6 \mathrm{mM})$ were similar to those found with glucose alone. However, by $30 \mathrm{~min}$ plasma glucose had decreased dramatically after GLP-1 administration, to levels significantly lower $(P<0.01)$ than those found with glucose alone, and glycaemic levels had virtually returned to basal by $60 \mathrm{~min}$. Area under the curve (AUC, 0-60 min, Fig. 4B) analysis showed that administration of GLP-1 significantly $(P<0 \cdot 001)$ reduced the overall glycaemic excursion compared with glucose alone. $\left(\mathrm{Abu}^{8}\right) \mathrm{GLP}-1$ acted with similar potency to GLP-1 also significantly reducing the AUC $(P<0.01)$ and returning glucose levels to basal by 60 min. $\left(\mathrm{Val}^{8}\right) \mathrm{GLP}-1$ was found to be significantly more effective than GLP-1 and $\left(\mathrm{Abu}^{8}\right) \mathrm{GLP}-1$ at reducing glycaemic AUG $(P<0.01)$ and at returning plasma glucose to a lower level at $60 \mathrm{~min}(P<0 \cdot 05)$.

Figure 5 shows the corresponding plasma insulin response of obese diabetic $(o b / o b)$ mice in this study. After injection of glucose alone, plasma insulin levels peaked at $15 \mathrm{~min}$ post administration to levels significantly higher $(P<0.001)$ than preinjection levels, returning to basal gradually over the remainder of the study. Although native GLP-1 induced a significantly greater insulin response $(17.9 \pm 0.6 \mathrm{mM} ; P<0.01)$ after $15 \mathrm{~min}$ compared with glucose, by $30 \mathrm{~min}$ the response to GLP-1 was not significantly different compared with glucose alone. Administration of $\left(\mathrm{Abu}^{8}\right)$ GLP-1 resulted in a similar plasma insulin profile to that found with GLP-1; however $\left(\mathrm{Val}^{8}\right)$ GLP-1 was found to evoke higher plasma insulin levels at $60 \mathrm{~min}(10 \cdot 0 \pm 0 \cdot 4$; $P<0.001)$ compared with both GLP-1 and $\left(\mathrm{Abu}^{8}\right)$ GLP-1. AUG analysis (Fig. 5B) confirmed the insulinotropic nature of GLP-1 with a significantly enhanced overall insulin response 

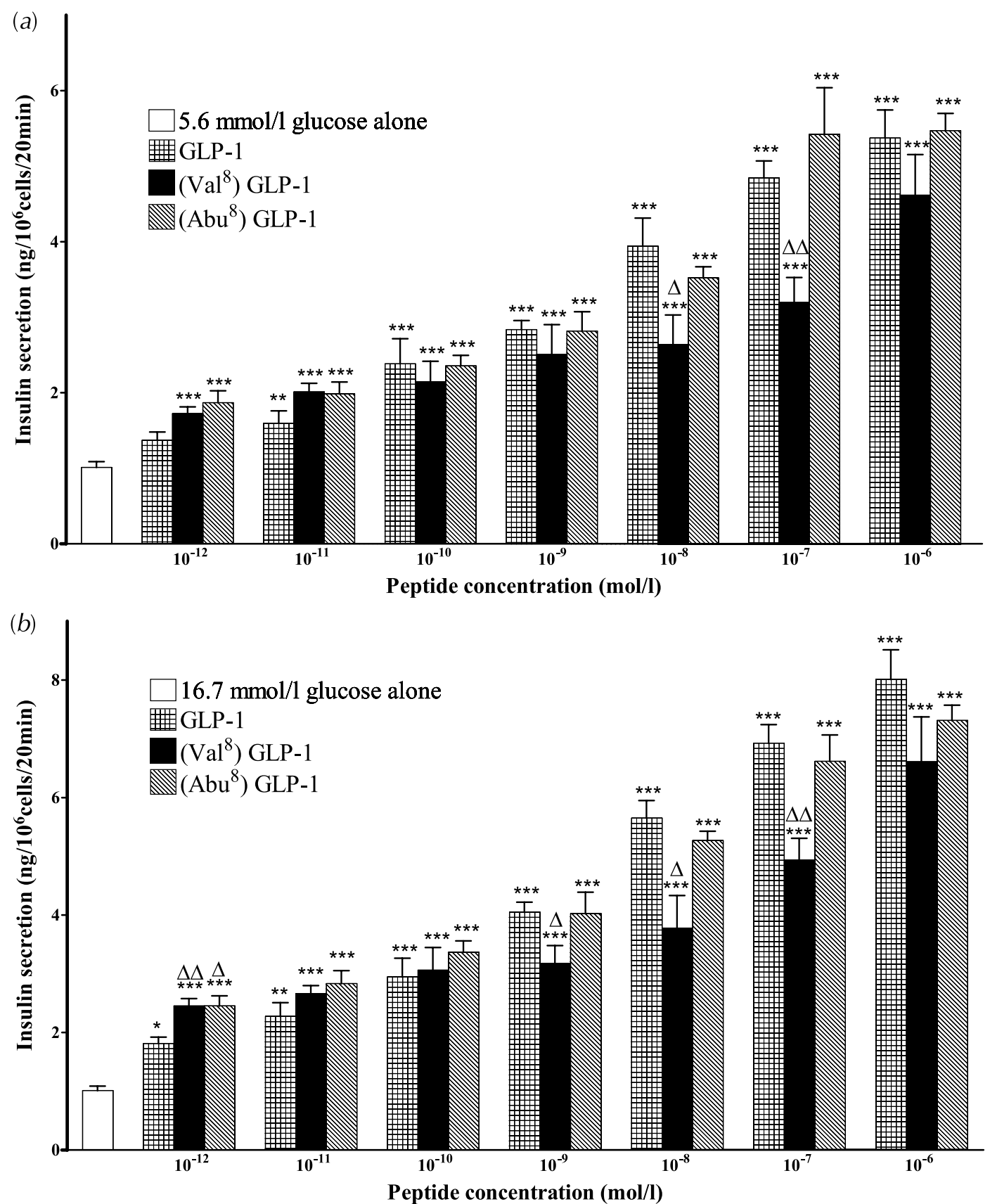

Figure 3 Insulinotropic effects of GLP-1, $\left(\mathrm{Abu}^{8}\right) \mathrm{GLP}-1$ and $\left(\mathrm{Val} \mathrm{l}^{8}\right) \mathrm{GLP}-1$ during acute 20 -min incubation of BRIN-BD11 cells in the presence of (A) $5.6 \mathrm{mM}$ or (B) $16.7 \mathrm{mM}$ glucose. Values represent the means \pm S.E.M. for eight separate observations. ${ }^{\star} P<0.05,{ }^{*} P<0.01,{ }^{\star * \star} P<0.001$ compared with glucose control. ${ }^{\triangle} P<0.05, \triangle \triangle P<0.01$ compared with native GLP-1 at the same concentration.

$(P<0.01) \quad$ compared with glucose alone. $\left(\mathrm{Abu}^{8}\right) \mathrm{GLP}-1$ and $\left(\mathrm{Val}^{8}\right) \mathrm{GLP}-1$ were also found to act with similar potency to GLP-1 significantly increasing the overall insulin response $(P<0.01$ to $P<0 \cdot 001)$.

\section{Discussion}

Classical insulinotropic secretagogues regularly used in the treatment of type 2 diabetes mellitus stimulate insulin secretion in an indiscriminate 

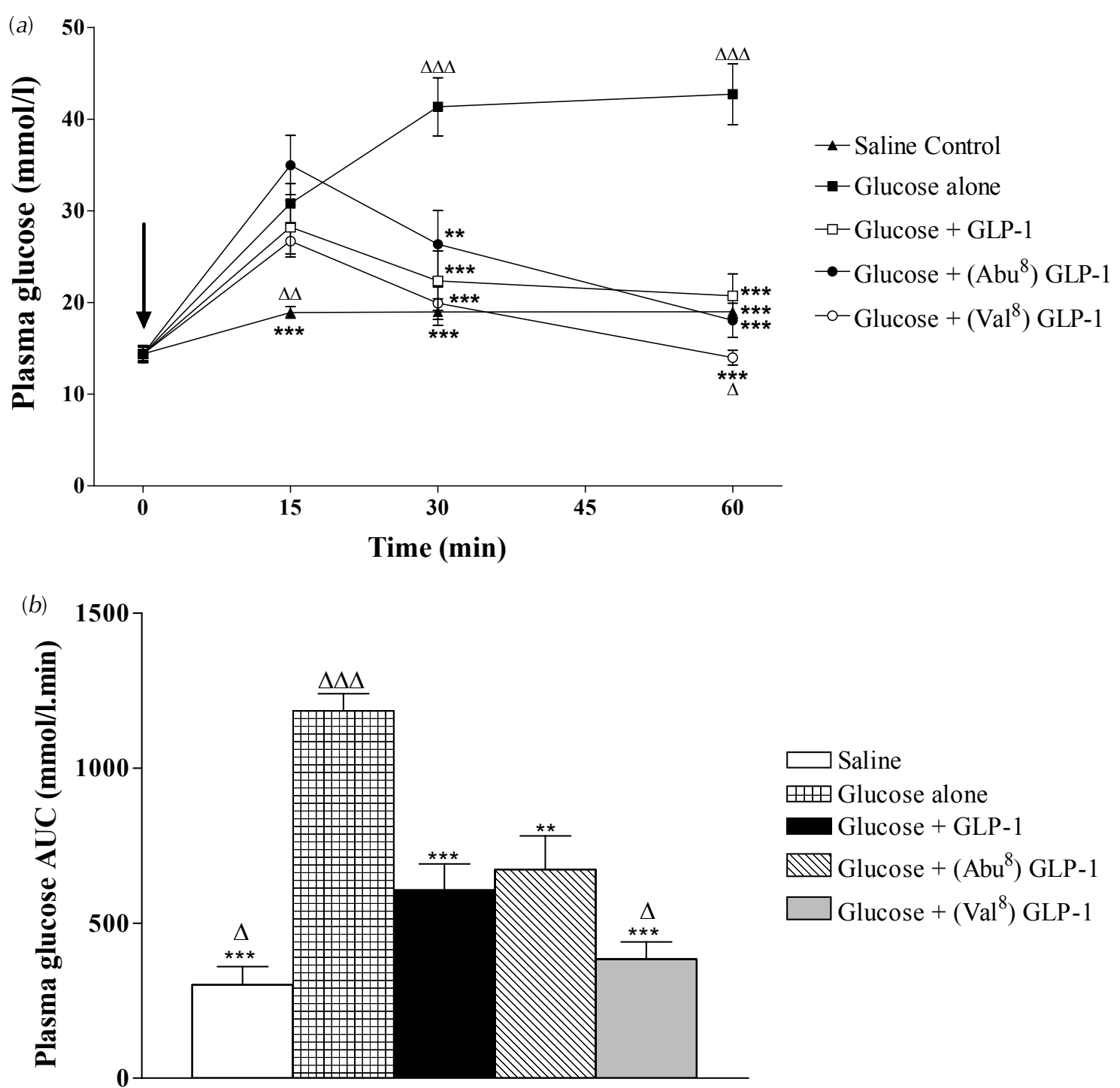

Figure 4 Glucose lowering effects of GLP-1, $\left(\mathrm{Abu}^{8}\right)$ GLP-1 and $\left(\left.\mathrm{Val}\right|^{8}\right) \mathrm{GLP}-1$ in 18-h fasted $(o b / o b)$ mice. (A) Plasma glucose concentrations were measured prior to and after i.p. administration of saline $(0.9 \%$ $(\mathrm{w} / \mathrm{v}) \mathrm{NaCl}$ ) as control, glucose alone (18 mmol/kg body weight), or in combination with native GLP-1, $\left(\mathrm{Abu}^{8}\right) \mathrm{GLP}-1$ or $\left(\mathrm{Val}^{8}\right) \mathrm{GLP}-1$ ( $25 \mathrm{nmol} / \mathrm{kg}$ body weight). The time of injection is indicated by the arrow (0 min). (B) Plasma glucose area under the curve (AUC) values for $0-60$ min post injection. Data represent the means \pm S.E.M. for eight mice. ${ }^{* \star} P<0.01$, ${ }^{* * *} P<0.001$ compared with glucose alone. $\triangle P<0.05, \triangle \triangle P<0.01, \triangle \triangle \triangle P<0.001$ compared with native GLP-1.

manner, regardless of glucose concentrations, and therefore put diabetic patients at risk of developing hypoglycaemia. The glucose-dependent nature of incretin hormone action prevents hypoglycaemic episodes occurring by only triggering insulin secretion under hyperglycaemic conditions, and therefore these hormones have become a very attractive basis for the generation of potential novel diabetic therapies (Bailey \& Flatt 1995).
Clinical studies using GLP-1 in human type 2 diabetic subjects have demonstrated that there is considerable therapeutic potential to be gained by the use of this hormone (Gutniak et al. 1992, Nauck et al. 1996, Zander et al. 2002). However, the rapid degradation of GLP-1 in the bloodstream by the enzyme DPP IV giving rise to the truncated and inactive GLP-1(9-36)amide is a major stumbling block to the efficient use of this hormone 

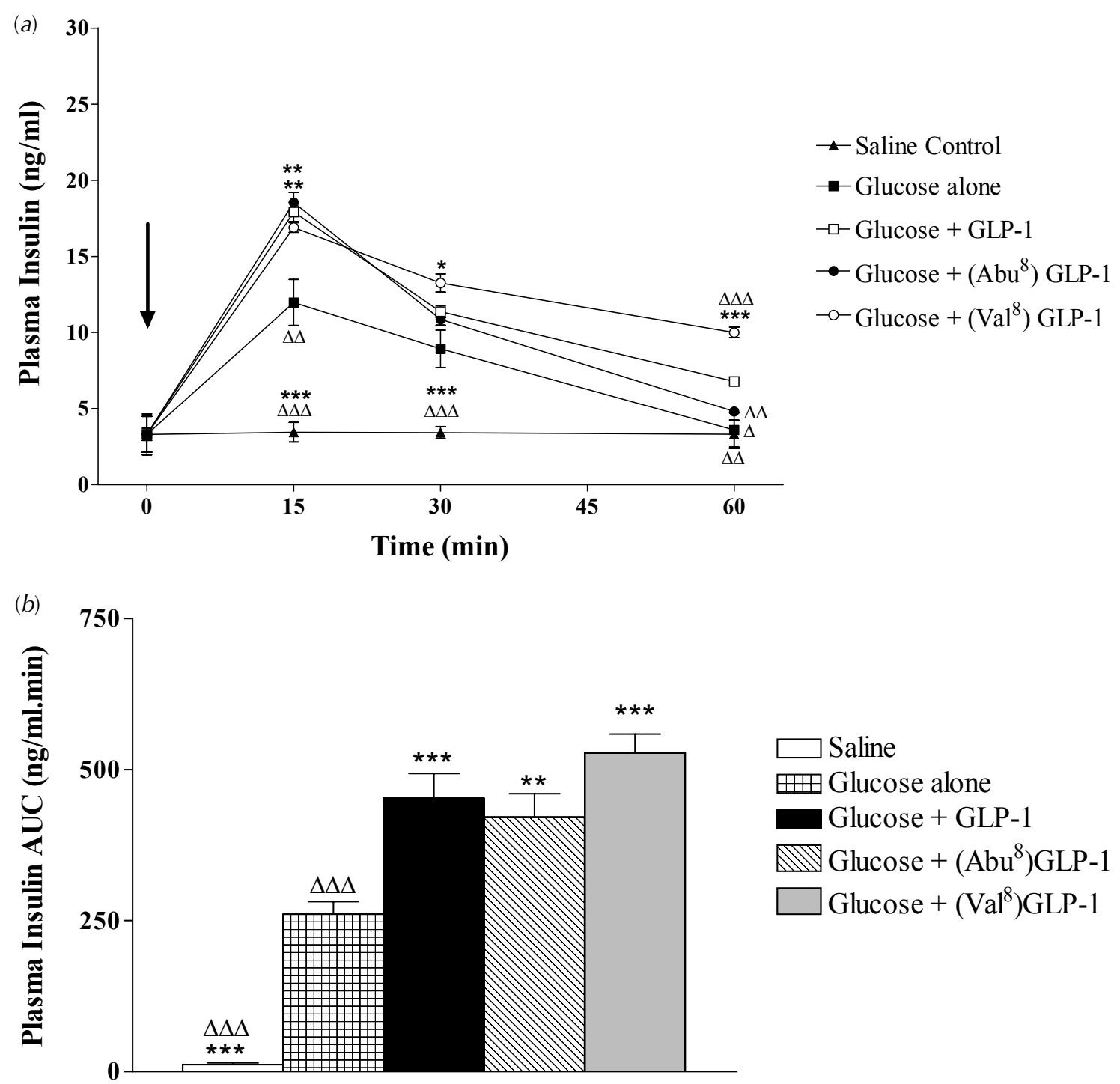

Figure 5 Insulin releasing effects of GLP-1, $\left(\mathrm{Abu}^{8}\right)$ GLP-1 and $\left(\mathrm{Val}^{8}\right) \mathrm{GLP}-1$ in 18-h fasted $(o b / o b)$ mice. (A) Plasma insulin concentrations were measured prior to and after i.p. administration of saline $(0.9 \%$ (w/v) $\mathrm{NaCl}$ ) as control, glucose alone (18 mmol/kg body weight), or in combination with native GLP-1, $\left(\mathrm{Abu}^{8}\right) \mathrm{GLP}-1$ or $\left(\mathrm{Val}^{8}\right) \mathrm{GLP}-1$ ( $25 \mathrm{nmol} / \mathrm{kg}$ body weight). The time of injection is indicated by the arrow (0 min). (B) Plasma insulin area under the curve (AUC) values for 0-60 min post injection. Data

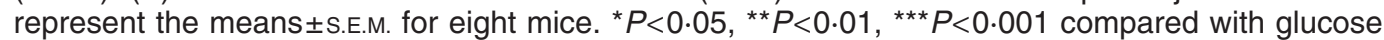
alone. $\triangle P<0.05, \triangle \triangle P<0.01, \triangle \triangle \triangle P<0.001$ compared with glucose + native GLP-1.

therapeutically (Mentlein et al. 1993, Kieffer et al. 1995). Administration of specific inhibitors of DPP IV have produced improved glucose tolerance in both animals (Sudre et al. 2002, Pospisilik et al. 2002) and humans (Ahren et al. 2002). However, as DPP IV is involved in diverse physiological processes including the inactivation of key regulatory hormones other than GLP-1 (Mentlein 1999), inhibition of DPP IV activity may not be a suitable means of prolonging the action of either endogenous or exogenous GLP-1. As a consequence, efforts are now focused towards the development of GLP-1 analogues which display resistance to DPP IV whilst maintaining the biological potency of the native hormone.

In this study, the penultimate alanine residue from the N-terminus of the GLP-1 peptide was replaced with either a valine or a 2-aminobutyric 
acid residue to generate two novel GLP-1 analogues - $\left(\mathrm{Val}^{8}\right)$ GLP-1 and $\left(\mathrm{Abu}^{8}\right)$ GLP-1. During in vitro incubation studies, native GLP-1 was progressively degraded over time by DPP IV and plasma. Both $\left(\mathrm{Val}^{8}\right) \mathrm{GLP}-1$ and $\left(\mathrm{Abu}^{8}\right) \mathrm{GLP}-1$ analogues proved to be completely resistant to proteolysis by DPP IV or plasma with no degradation products detected even after 12-h incubation. This suggests that increasing the size of the amino acid side chain at $\mathrm{Ala}^{8}$, achieved by substituting for either valine or 2-aminobutyric acid, drastically reduces the specificity of DPP IV for GLP-1. This finding is in accordance with previous studies, where $\mathrm{Ala}^{8}$ of GLP-1 was substituted with glycine (Deacon et al. 1998, Burcelin et al. 1999, Siegel et al. 1999, Doyle et al. 2001), serine (Deacon et al. 1998, Ritzel et al. 1998, Siegel et al. 1999), D-alanine (Siegel et al. 1999), threonine or $\alpha$-aminoisobutyric acid (Deacon et al. 1998).

Although modified at the N-terminus, both $\left(\mathrm{Val}^{8}\right)_{\text {GLP-1 }}$ and $\left(\mathrm{Abu}^{8}\right)$ GLP-1 retained biological activities normally associated with native GLP-1. Receptor binding studies demonstrated that $\left(\mathrm{Val}^{8}\right)$ GLP-1 and $\left(\mathrm{Abu}^{8}\right)$ GLP-1 bound with high affinity to the GLP-1 receptor, dose-dependently displacing ${ }^{125}$ I-labelled GLP-1. However, these receptor affinities were reduced compared with native GLP-1. Additionally, although potent stimulators of intracellular cAMP,$\left(\mathrm{Val}^{8}\right) \mathrm{GLP}-1$ and $\left(\mathrm{Abu}^{8}\right)$ GLP-1 were, respectively, 1.5- and 3.5-fold less potent than native GLP-1. Taken together with previous data (Siegel et al. 1999), these observations indicate that a loss in receptor binding of $\mathrm{Ala}^{8}$-substituted analogues usually results in a loss in adenylate cyclase activity. However, in the present study losses in receptor affinity and cAMP production were not translated into losses in insulinotropic activity due to diverse mechanisms of GLP-1 action on $\beta$ cells (MacDonald et al. 2002). $\left(\mathrm{Val}^{8}\right)$ GLP-1 and $\left(\mathrm{Abu}^{8}\right)$ GLP-1 maintained dose-dependent insulinotropic activity similar to GLP-1 at both basal and elevated glucose concentrations in vitro. The effects of $\left(\mathrm{Abu}^{8}\right) \mathrm{GLP}-1$ were particularly impressive and at elevated glucose both analogues were found to be more potent than GLP-1 at the lowest concentration tested.

When administered to diabetic $(o b / o b)$ mice, these novel GLP-1 analogues significantly lowered plasma glucose levels. Whilst $\left(\mathrm{Abu}^{8}\right) \mathrm{GLP}-1$ had similar in vivo glucose-lowering ability as native GLP-1, $\left(\mathrm{Val}^{8}\right)^{\circ}$ GLP-1 was significantly more potent, reducing the overall glucose excursion by $37 \%$ more than native GLP-1. This glucose lowering activity was associated with increased insulin levels and GLP-1, $\left(\mathrm{Abu}^{8}\right)$ GLP-1 and $\left(\mathrm{Val}^{8}\right)$ GLP-1 appeared equipotent as insulin secretagogues in vivo. The more potent antihyperglycaemic activity of $\left(\mathrm{Val}^{8}\right)$ GLP-1 may therefore relate to other beneficial actions such as inhibition of glucagon secretion or extrapancreatic effects (Fehmann et al. 1995). Other modifications of the GLP-1 molecule through substitution of $\mathrm{Ala}^{8}$ have also been reported. $\left(\mathrm{Gly}^{8}\right)$ GLP-1 lowered blood glucose (Burcelin et al. 1999) and increased insulin secretion (Doyle et al. 2001) in diabetic mice and rats; however, this was less effective than native peptide. Also notable was $\left(\mathrm{Ser}^{8}\right)$ GLP-1 which possessed enhanced insulinotropic and glucose-lowering activity in normal animals (Ritzel et al. 1998). Although comparison of the relative effectiveness of $\left(\mathrm{Abu}^{8}\right)$ GLP-1 and $\left(\mathrm{Val}^{8}\right)$ GLP-1 with these analogues is difficult due to differences in experimental design, it is clear that $\left(\mathrm{Abu}^{8}\right) \mathrm{GLP}-1$ and particularly $\left(\mathrm{Val}^{8}\right)_{\text {GLP-1 }}$ rate favourably in terms of potency and spectrum of actions.

In conclusion, this study demonstrates that substitution of the $\mathrm{Ala}^{8}$ residue of GLP-1 by either valine or 2-aminobutyric acid confers resistance to DPP IV degradation without impairing insulin release or biological action in vivo. $\left(\mathrm{Val}^{8}\right) \mathrm{GLP}-1$ exhibited increased antihyperglycaemic activity in $o b / o b$ mice, also indicating important actions distinct from the stimulation of insulin secretion. This study lends support to the belief that GLP-1 analogues modified at the $\mathrm{Ala}^{8}$ position, such as $\left(\mathrm{Val}^{8}\right)$ GLP-1, could be worthwhile therapeutic candidates for the treatment of type 2 diabetes mellitus.

\section{Acknowledgements}

These studies were supported by the University of Ulster Research Strategy Funding and Research and Development Office of Health and Personal Social Services for N. Ireland. The authors wish to thank Professor Bernard Thorens (University of Lausanne, Switzerland) for kindly providing the Chinese hamster lung fibroblast (CHL) cells transfected with the human GLP-1 receptor. 


\section{References}

Abraham EJ, Leech CA, Lin JC, Zulewski H \& Habener JF 2002 Insulinotropic hormone glucagon-like peptide-1 differentiation of human pancreatic islet-derived progenitor cells into insulin-producing cells. Endocrinology 143 3152-3161.

Ahren B, Simonsson E, Larsson H, Landin-Olsson M, Torgeirsson H, Jansson P-A, Sandqvist M, Bavenholm P, Efendic S, Eriksson J, Dickinson S \& Holmes D 2002 Inhibition of dipeptidyl peptidase IV improves metabolic control over a 4-week study period in type 2 diabetes. Diabetes Care 25 869-875.

Bailey CJ \& Flatt PR 1995 Development of antidiabetic drugs. In Drugs, Diet and Disease: Mechanistic Approaches to Diabetes, pp 279-326. Eds C Ionnides \& PR Flatt. London: Ellis Horwood.

Bailey CJ, Flatt PR \& Atkins TW 1982 Influence of genetic background and age on the expression of the obese hyperglycaemic syndrome in Aston ob/ob mice. International Journal of Obesity 6 11-21.

Barrett AJ \& Rawlings ND 1992 Oligopeptidases, and the emergence of the prolyl oligopeptidase family. Biological Chemistry Hoppe-Seyler 373 353-360.

Bell GI, Sanchez-Pescador R, Laybourn PJ \& Najarian RC 1983 Hamster preproglucagon contains the sequence of glucagon and two related peptides. Nature 302 716-718.

Bullock BP, Heller RS \& Habener JF 1996 Tissue distribution of messenger ribonucleic acid encoding the rat glucagon-like peptide receptor. Endocrinology 137 2968-2978.

Burcelin R, Dolci W \& Thorens B 1999 Long-lasting antidiabetic effects of a dipeptidyl peptidase IV-resistant analog of glucagon-like peptide-1. Metabolism 48 252-258.

Burington RS 1973 Handbook of Mathematical Tables and Formulas. New York: McGraw-Hill.

Deacon CF, Knudsen LB, Madsen K, Wiberg FC, Jacobsen O \& Holst JJ 1998 Dipeptidyl peptidase IV resistant analogues of glucagon-like peptide-1 which have extended metabolic stability and improved biological activity. Diabetologia 41 271-278.

Doyle ME, Greig NH, Holloway HW, Betkey JA, Bernier M \& Egan JM 2001 Insertion of an N-terminal 6-aminohexanoic acid after the 7 amino acid position of glucagon-like peptide- 1 produces a long-acting hypoglycaemic agent. Endocrinology 142 $4462-4468$

Fehmann HC \& Habener JF 1992 Insulinotropic hormone glucagon-like peptide-1 (7-37) stimulation of proinsulin gene expression and proinsulin biosynthesis in insulinoma beta TC-1 cells. Endocrinology 130 159-166.

Fehmann HC, Goke R \& Goke B 1995 Cell and molecular biology of the incretin hormones glucagon-like peptide-1 and glucose-dependent insulin releasing polypeptide. Endocrine Reviews $16390-410$

Fields GB \& Noble RL 1990 Solid phase peptide synthesis utilizing 9-fluorenylmethoxycarbonyl amino acids. International foumal of Peptide and Protein Research 35 161-214.

Flatt PR \& Bailey CJ 1981 Abnormal plasma glucose and insulin responses in heterozygous lean $(o b /+)$ mice. Diabetologia 20 573-577.

Gutniak M, Orskov C, Holst JJ, Ahren B \& Efendic S 1992 Antidiabetogenic effect of glucagon-like peptide-1(7-36) amide in normal subjects and patients with diabetes mellitus. New England Journal of Medicine 326 1316-1322.

Iwaki-Egawa S, Watanabe Y, Kikuya Y \& Fujimoto Y 1998 Dipeptidyl peptidase IV from human serum: purification, characterization, and $\mathrm{N}$-terminal amino acid sequence. Fournal of Biochemistry 2 428-433.

Kieffer TJ, McIntosh CHS \& Pederson RA 1995 Degradation of glucose-dependent insulinotropic polypeptide and truncated glucagon-like peptide 1 in vitro and in vivo by dipeptidyl peptidase IV. Endocrinology 136 3585-3596.
Knudsen LB \& Pridal L 1996 Glucagon-like peptide-1-(9-36) amide is a major metabolite of glucagon-like peptide-1-(7-36) amide after in vivo administration to dogs, and it acts as an antagonist on the pancreatic receptor. European Fournal of Pharmacology $\mathbf{3 1 8}$ 429-435.

Kreymann B, Ghatei MA, Williams G \& Bloom S 1987 Glucagon-like peptide-1(7-36): a physiologic incretin in man. Lancet 2 1300-1304.

McClenaghan NH, Barnett CR, Ah-Sing E, Abdel-Wahab YHA, O'Harte FPM, Yoon T-W, Swanston-Flatt SK \& Flatt PR 1996 Characterization of a novel glucose-responsive insulin-secreting cell line, BRIN-BD11, produced by electrofusion. Diabetes $\mathbf{4 5}$ $1132-1140$

MacDonald PE, El-kholy W, Riedel MJ, Salapatek AMF, Light PE \& Wheeler MB 2002 The multiple actions of GLP-1 on the process of glucose-induced insulin secretion. Diabetes $\mathbf{5 1}$ S434-S442.

Mentlein R 1999 Dipeptidyl-peptidase IV (CD26) - role in the inactivation of regulatory peptides. Regulatory Peptides $\mathbf{8 5}$ 9-24.

Mentlein R, Gallwitz B \& Schmidt WE 1993 Dipeptidyl-peptidase IV hydrolyses gastric inhibitory polypeptide, glucagon-like peptide-1(7-36)amide, peptide histidine methionine and is responsible for their degradation in human serum. European fournal of Biochemistry 214 829-835.

Miguel JC, Abdel-Wahab YH, Green BD, Mathius PC \& Flatt PR 2003 Cooperative enhancement of insulinotropic action of GLP-1 by acetylcholine uncovers paradoxical inhibitory effect of beta cell muscarinic receptor activation on adenylate cyclase activity. Biochemical Pharmacology 65 283-292.

Nathan DM, Schreiber E, Fogel H, Mojsov S \& Habener JF 1992 Insulinotropic action of glucagon-like peptide-1-(7-37) in diabetic and non-diabetic patients. Diabetes Care 15 270-276.

Nauck MA, Wollschlager D, Werner J, Holst JJ, Orskov C, Creutzfeldt W \& Willms B 1996 Effects of subcutaneous glucagon-like peptide 1 (GLP-1[7-36 amide]) in patients with NIDDM. Diabetologia 39 1546-1553.

Oben J, Morgan L, Fletcher J \& Marks V 1991 Effect of the enteropancreatic hormones gastric inhibitory polypeptide and glucagon-like peptide-1(7-36)amide on fatty acid synthesis in explants of rat adipose tissue. Fournal of Endocrinology $\mathbf{1 3 0}$ 267-272.

O'Harte FPM, Gray AM, Abdel-Wahab YHA \& Flatt PR 1997 Effects of glycated and non-glycated GLP-1(7-36) amide on glucose metabolism in muscle. Peptides 18 1327-1333.

O'Harte FPM, Mooney MH, Kelly CMN, McKillop AM \& Flatt PR 2001 Degradation and glycaemic effects of His7-glucitol glucagon-like peptide-1(7-36)amide in obese diabetic ob/ob mice. Regulatory Peptides 96 95-104.

Perea A, Vinambres C, Glemente F, Villanueva-Peñacarrillo ML \& Valverde I 1997 GLP-1 (7-36) amide: effects on glucose transport and metabolism in rat adipose tissue. Hormone Metabolic Research 29 $417-421$

Pospisilik JA, Stafford SG, Demuth H-U, Brownsey R, Parkhouse W, Finegood DT, McIntosh CHS \& Pederson RA 2002 Long-term treatment with the dipeptidyl peptidase IV inhibitor P32/98 causes sustained improvements in glucose tolerance, insulin sensitivity, hyperinsulinemia, and $\beta$-cell glucose responsiveness in VDF (fa/fa) Zucker rats. Diabetes 51 943-950.

Rachman J, Gribble FM, Barrow BA, Levy JC, Buchanan KD \& Turner RC 1996 Normalization of insulin responses to glucose by overnight infusions of glucagon-like peptide 1 (7-36) amide in patients with NIDDM. Diabetes 45 1524-1530.

Ritzel U, Orskov C, Holst JJ \& Nauck MA 1995 Pharmacokinetic, insulinotropic, and glucagonostatic properties of GLP-1(7-36 amide) after subcutaneous injection in healthy volunteers. Dose-response relationships. Diabetologia 38 720-725. 
Ritzel U, Leonhardt U, Ottleben M, Rühmann A, Eckart K, Speiss J \& Ramadori G 1998 A synthetic glucagon-like peptide-1 analogue with improved plasma stability. Fournal of Endocrinology 159 93-102.

Salacinski PR, McLean C, Sykes JE, Clement-Jones VV \& Lowry PJ 1981 Iodination of proteins, glycoproteins, and peptides using a solid-phase oxidizing agent, 1,3,4,6-tetrachloro-3 alpha, 6 alpha-diphenyl glycoluril (Iodogen). Analytical Biochemistry 117 136-146.

Siegel EG, Gallwitz B, Scharf G, Mentlein R, Morys-Wortmann C, Folsch UR, Schrezenmeir J, Drescher K \& Schmidt WE 1999 Biological activity of GLP-1 analogues with N-terminal modifications. Regulatory Peptides 79 93-102.

Stevens JF 1971 Determination of glucose by an automatic analyser. Clinica Chimica Acta 32 199-201.

Sudre B, Broqua P, White R, Ashworth D, Evans D, Haigh R, Junien J-L \& Aubert M 2002 Chronic inhibition of circulating dipeptidyl peptidase IV by FE 999011 delays the occurrence of diabetes in male Zucker diabetic fatty rats. Diabetes 51 1461-1469.

Thorens B, Porret A, Buhler L, Deng S-P, Morel P \& Widmann C 1993 Cloning and functional expression of the human islet GLP-1 receptor. Diabetes 42 1678-1682.

Tourrel C, Bailbe D, Lacorne M, Meile M-J, Kergoat M \& Portha B 2002 Persistant improvement of type 2 diabetes in the Gotto-Kakizaki rat model by expansion of the B-cell mass during the prediabetic period with glucagon-like peptide-1 or exendin-4. Diabetes 51 1443-1452.

Turton MD, O'Shea D, Gunn I, Beak SA, Edwards CMB, Meeran K, Choi SJ, Taylor GM, Heath MM, Lambert PD, Wilding JPH,
Smith DM, Ghatei MA, Herbert J \& Bloom SR 1996 A role for glucagon-like peptide- 1 in the central regulation of feeding. Nature 379 69-72.

Valverde I, Morales M, Clemente F, Lopez-Delgado MI, Delgado E, Perea A \& Villanueva-Peñacarrillo ML 1994 Glucagon-like peptide 1: a potent glycogenic hormone. FEBS Letters 349 313-316.

Villanueva-Peñacarrillo ML, Alcantara AI, Clemente F, Delgado E \& Valderde I 1994 Potent glycogenic effect of GLP-1(7-36)amide in rat skeletal muscle. Diabetologia 37 1163-1166.

Wang Y, Perfetti R, Greig NH, Holloway HW, DeOre KA, Montrose-Rafizadeh C, Elahi D \& Egan JM 1997 Glucagon-like peptide-1 can reverse the age-related decline in glucose tolerance in rats. Fournal of Clinical Investigation 99 2883-2889.

Wettergren A, Scjholdager B, Mortensen PE, Myhre J, Christiansen J \& Holst JJ 1993 Truncated GLP-1 (proglucagon 78-107 amide) inhibits gastric and pancreatic functions in man. Digestive Diseases and Sciences 38 665-673.

Wettergren A, Wojdemann M \& Holst JJ 1998 The inhibitory effect of glucagon-like peptide-1 (7-36)amide on antral motility is antagonized by its N-terminally truncated metabolite GLP-1 (9-36)amide. Peptides 19 877-882.

Zander M, Madsbad S, Lysgaard Madsen J \& Holst JJ 2002 Effect of 6 -week course of glucagon-like peptide 1 on glycaemic control, insulin sensitivity, and B-cell function in type 2 diabetes: a parallel-group study. Lancet 359 824-830.

Received in final form 29 August 2003

Accepted 5 September 2003 